\title{
Explicit Evidence of an Implicit Contract*
}

\author{
Andrew T. Young \\ College of Business and Economics \\ Department of Economics, West Virginia University \\ Morgantown, WV 26505-6025, USA \\ Andrew.Young@mail.wvu.edu \\ Daniel Levy** \\ Department of Economics, Bar-Ilan University \\ Ramat-Gan 52900, ISRAEL, \\ Department of Economics, Emory University \\ Atlanta GA, 30322, USA, and \\ Rimini Center for Economic Analysis, ITALY \\ Daniel.Levy@biu.ac.il
}

JEL Codes: E12, E31, K00, K12, K22, K23, L14, L16, L66, M21, M31, N80, A14

Keywords: Implicit Contract, Explicit Contract, Invisible Handshake, Customer Market, Long-Term Relationship, Price Rigidity, Sticky Prices, Price Adjustment, Quality Rigidity, Quality Adjustment, Nickel Coke, Coca-Cola, Secret Formula, Real Thing

Last Revision: August 19, 2013

\begin{abstract}
* We thank three anonymous referees for thoughtful comments and suggestions which we found very constructive and helpful. We are particularly grateful to the editor, Al Klevorick, for his advice and painstaking guidance through the multiple revision process. We thank Robert Barsky, Susanto Basu, Benny Bental, Mark Bergen, Steve Cecchetti, Robert Chirinko, Alex Cukierman, Leif Danziger, Stanley Fischer, Ben Friedman, Zvi Hercowitz, Arye Hillman, Mark Hooker, Simon Gächter, Robert Gordon, Anil Kashyap, Robert King, Pete Klenow, Ed Knotek, Saul Lach, Jon Moen, Walter Oi, Will Roberds, Christina Romer, David Romer, Julio Rotemberg, Paul Rubin, Rob Saur, Matthew Shapiro, Avichai Snir, Robert Solow, Peter Temin, Ken West, Jon Willis, Janet Yellen, and Mor Zahavi for providing useful comments and suggestions on earlier versions of the paper. We thank also the seminar participants at Bar-Ilan University, Ben-Gurion University, European Central Bank, Emory University, University of Haifa, Hebrew University, ISET, University of Michigan, NBER, and Tel-Aviv University, as well as the participants of the 2008 Annual Conference of the European Association of Law and Economics at the University of Haifa for suggestions and advice. We also thank the Coca-Cola Company Archive employees and especially Phil Mooney, the Coca-Cola Company Historian and the Coca-Cola Company Archive Director, for helping us locate many of the materials used for this project and for patiently answering our questions, and Virginia Cain and Kathy Shoemaker, Emory University Archivists of the Special Collections, for helping us with the papers and correspondence material contained in the Robert W. Woodruff Collection at the Emory University Special Collection Library. Daniel Levy acknowledges financial support from the University Research Committee at Emory University and from Adar Foundation at the Department of Economics at Bar-Ilan University, and research assistance of Eleana Aguilar, Xia Liu, and the late Yihong Xia. Some parts of the manuscript were written at the Monetary Policy Research Division of the European Central Bank in Frankfurt, where Daniel Levy was a visiting scholar. He gratefully acknowledges the Bank's hospitality and research support. All errors are ours.

** Correspondence: Daniel Levy: Daniel.Levy@biu.ac.il.
\end{abstract}

Forthcoming: Journal of Law, Economics, \& Organization 


\title{
Explicit Evidence of an Implicit Contract
}

\begin{abstract}
We offer the first direct evidence of an implicit contract in a goods market. The evidence comes from the market for Coca-Cola. Since implicit contracts are unobservable, we adopt a narrative approach to demonstrate that the Coca-Cola Company left a written evidence of the implicit contract with its customers - a very explicit form of an implicit contract. The implicit contract promised a $6.5 \mathrm{oz}$ Coca-Cola of a constant quality, the "secret formula," at a constant price, $5 \varnothing$. We show that Coca-Cola attributes and market structure made it a suitable candidate for an implicit contract. Focusing on the observable implications of such an implicit contract, we offer evidence of the Company both acknowledging and acting on this implicit contract, which was valued by consumers. During a period of 74 years, we find evidence of only a single case of true quality change. We demonstrate that the company perceived itself as vulnerable to consumer backlash by reneging on the pledge, and conclude that the perceived costs of breaking the implicit contract were large.
\end{abstract}




\section{Introduction}

Okun (1981) popularized "invisible handshakes," or implicit contracts, as a possible source of price rigidity. They have most often been explored in the context of wage setting in labor markets (Rosen, 1985, 1994). However, implicit contracts may plausibly exist in consumer goods markets as well. ${ }^{1}$ To our knowledge, however, no studies offer direct evidence of this. ${ }^{2}$ We offer the first direct and, in fact, quite explicit evidence of such an implicit contract. The evidence comes from the market for Coca-Cola.

Starting in 1886 , in the bottle or at the fountain, $6.5 \mathrm{oz}$ of Coca-Cola retailed for $5 \varnothing$. With remarkably few deviations, this nominal price did not adjust for over 60 years. The nickel Coke did not entirely disappear from US markets until 1959—over 70 years!

During this time there was also remarkable quality rigidity with less than one change per decade on average to the "Secret Formula" (Levy and Young, 2004). We argue that an implicit contract with consumers was associated with both the price and quality rigidity.

The lack of studies offering direct evidence of implicit contracts is not surprising as they are "tacit agreements that are not written down [and] the theory does not predict literal price rigidity, but only that prices are relatively insensitive to fluctuations in demand" (Blinder, et al., 1988, p. 152). As "hard" data are hard to come by, we adopt a narrative approach (Romer and Romer, 1989, 1994; Zbaracki, et al., 2004). ${ }^{3}$

The Coca-Cola price rigidity is exceptional relative to the evidence reported on US prices. ${ }^{4}$ Cecchetti (1986) reports that magazine prices change only every 3-6 years on

\footnotetext{
${ }^{1}$ Okun (1981) introduced the term "customer markets" to refer to those goods markets where long-term relationships can exist between sellers and buyers.

${ }^{2}$ Renner and Tyran (2004) present experimental evidence that long-term relationships based on trust can form to mitigate "lemons" problems when cost shocks are difficult for consumers to discern.

${ }^{3}$ As Romer and Romer (1989) emphasize, a narrative approach allows one to exploit a large body of soft data containing qualitative information that is difficult to employ in conventional econometric studies. ${ }^{4}$ Earlier survey studies summarizing this literature include Rotemberg (1987), Gordon (1991), Weiss (1993), and Romer (1993). For more recent surveys, see Willis (2003), Levy (2007), Wolman (2007), Klenow and Malin (2010), and Leahy (2011). Several studies conducted by the European Central Bank and
} 
average. Using business-to-business industrial price data, Carlton (1986) finds that prices remain unchanged for several years. Kashyap (1995) studies catalog prices of 12 retail goods for 35 years and reports an average duration of 15 months. Blinder, et al. (1988), based on survey evidence from firms, conclude that, on average, prices lag supply or demand changes by 3 months. ${ }^{5}$ Recent studies using micro-level transaction price data report similar figures (e.g., Nakamura and Steinsson, 2008; Nakamura and Zerom, 2010). ${ }^{6}$ In comparison, the Coca-Cola price rigidity lasted at least an order of magnitude longer.

The Coca-Cola Company is one of the most successful and recognized producers of a consumer good in the world. During the time period we study, the soft drink industry and the Coca-Cola Company itself were non-negligible parts of the US economy. For example, in 1945 the bottled non-alcoholic carbonated beverage industry was $0.26 \%$ of US GDP (Riley, 1942, p. 343). The Company had a roughly 50\% market share in that industry, making its own contribution an economically significant $0.13 \%$ of GDP.

In Levy and Young (2004) we argue that an explicit contract between Coca-Cola and its bottlers was a source of price rigidity. The contract fixed the price of Coca-Cola syrup to bottlers. Given this, the Company could increase profits only by selling more syrup. Thus the Company pursued a policy of retail price maintenance. ${ }^{7}$ The contract, however,

its member EU central banks report that EU prices tend to be more rigid than US prices. Álvarez, et al, (2006), Dhyne, et al. (2006), and Levy and Smets (2010) summarize these studies.

${ }^{5}$ Levy et al. (2002), Genesove (2003) and Young and Blue (2007) document price rigidities for, respectively, orange juice products (about a month), apartment rental rates (a few months), and goods sold through Sears catalogs (over two years in some cases). Some studies, however, report more frequent price changes (e.g., Levy, et al., 1997; Dutta, et al., 1999; Dutta, et al., 2002; Bills and Klenow, 2004).

${ }^{6}$ See also Goldberg and Hellerstein $(2007,2013)$, Anderson and Simester (2010), Gopinath and Itskhoki (2010, 2011), Chevalier and Kashyap (2011), and Anderson, et al. (2012).

${ }^{7}$ Two technology-based factors help to explain the continuation of the nickel price beyond 1921. First, the vending machines with nickel-only capability and limited change-making technology imposed a constraint on price adjustment. Second, the smallest price increase compatible with consumers using a single coin was $100 \%$. A monetary transaction technology for smaller price adjustments, keeping consumer "inconvenience costs" low, was not available. Daly (1970) documents widespread consumer inconvenience costs due to a small change shortage in Brazil. Selgin (2008) documents how in late 1700s UK private coinage flourished in response to a shortage of smaller denomination coins. In Knotek (2008), firms incorporate convenience 
lasted until 1921 and cannot explain the additional 38 years of price rigidity.

Here we address the presence of an implicit contract between Coca-Cola and its consumers. We argue that it was an important source of the price rigidity during 1921-1959. However, we stress that the explicit contract with bottlers and the implicit contract with consumers are related: the former contributed to and reinforced the latter.

We argue that the implicit contract included the promise of a constant price and constant quality. We document the dedication to the $6.5 \mathrm{oz}$ serving of the Secret Formula. Over a 73-year period, only seven changes in the Secret Formula occurred. Of those, we argue that only one could have been substituted for by a price adjustment.

In section 2 we document the Coca-Cola price and quality rigidities and discuss changes in economic conditions and marginal costs. In section 3 we describe implicit contracts and the problems that they can solve, and show that the Company perceived such problems as important. In section 4 we present our evidence of an implicit contract. In section 5 we address the link between the implicit and explicit contracts. We consider some alternative explanations for the nickel Coke in section 6 and conclude in section 7.

\section{The Coca-Cola Episode: Price and Quality Rigidity}

The nickel Coke began in 1886 with an Atlanta peddler of patent medicines. John Stith Pemberton had the ingenious idea to sell Coca-Cola in $5 \varnothing$ fountain servings rather than in $75 \not$ or $\$ 1$ medicine bottles. The world's most famous soft drink was born. If he were alive, Pemberton might well be shocked to learn that the nickel Coke remained largely uniform for over 60 years and did not disappear for over 70 years.

Whether in a bottle or at a soda fountain, $6.50 z$ Coca-Cola retailed for $5 \varnothing$. The

into pricing decisions. The model can account for the dynamics of US newspaper prices. Knotek (2011) extends the evidence to convenience store products. Eckard (2007) argues that relatively few "even" price points reduced cashier transaction costs. 
remarkably few exceptions were unpopular with consumers. As late as 1951, Fortune magazine reported that Louisiana dealers, seeking to pass on cost increases to consumers, had to backtrack as consumers threatened to "take all their business elsewhere [...]" "Everybody knows Coke sells for a nickel - look at the back of this week's Life" (p. 129).

During the more than 70 years of price rigidity, Coca-Cola also exhibited remarkable quality rigidity. Schaeffer and Bateman (1985) document merely six changes in the Secret Formula from 1886 to 1960 . We found evidence of one additional, temporary change. Two of the changes were exogenously imposed. All but one of the other changes were attempts to keep quality unchanged. Since we argue that constant quality was a part of the implicit contract, we elaborate briefly on each Formula change.

The first documented change was an addition of glycerin in 1889 to prevent the syrup from turning rancid in storage. The syrup was also altered by "adding essential ingredients and by taking others out of the Pemberton Formula" in order to make the ingredients more "compatible" with each other (Schaeffer and Bateman, 1985, p. 4). By all accounts, these changes were made to prevent perishing and ensure constant quality at different fountain locations.

In 1899 the second documented change occurred. The Company decided to prepare two syrups - one for fountains and one for bottles. The syrup for bottles contained more sugar, less water, more caramel, more citric acid, less caffeine, and more phosphoric acid (Allen, 1994, p. 9). The goal was to ensure that the drink, at the fountain or from a bottle, had the same taste; that is, to ensure uniform quality.

The third change was the indirect result of an 1898 tax on medicines. Coca-Cola was still marketed as a medicine and a tax of $\$ 29,502$ was charged, which the Company contested. At trial in 1901, Company president Asa Candler admitted under oath to Coca- 
Cola having "a very small trace" of cocaine. ${ }^{8}$ The Company outsourced the preparation of "Merchandise No. 5" (containing coca leaf and kola nut extracts) to remove the cocaine completely. This change was made under exogenous threat of prosecution.

The fourth change came in 1904. The Company was using powdered sugar which carried moisture and tended to sour during transportation (Candler, 1950). A switch to granulated sugar was made. ${ }^{9}$ Since we find no evidence of consumers perceiving a change in quality, the two sugar types were likely perfect (or very close) substitutes.

A lawsuit brought by the USDA under the Pure Food and Drug Act of 1906 led to the fifth change. The 1909 lawsuit claimed Coca-Cola was "misbranded" because its name promised kola and coca but contained little of either; and it was "adulterated" by added caffeine. ${ }^{10}$ In April 1918, the Company agreed to a settlement which included reducing the caffeine by almost two-thirds. This change was exogenously imposed.

The sixth change occurred when, in response to WWI sugar shortages and rationing, Company president Howard Candler (Asa's son) stockpiled sugar at 28 $4 / \mathrm{lb}$ (almost four times its pre-war price). When the price of sugar then plummeted (Atlanta Georgian, February 15,1921$)$ the Company found itself committed to over $\$ 8$ million on sugar at twice the going price (Landers, 1950). To avoid future replays, the Company developed syrup based on beet sugar. ${ }^{11}$ With the help of a German scientist, the Company developed a beet sugar that did not change Coca-Cola's flavor.

We found evidence of one additional (temporary) Secret Formula change. In 1942, WWII sugar shortages led Company president Robert Woodruff to reluctantly approve

\footnotetext{
${ }^{8}$ As a result, Coca-Cola was banned at the military canteen and post exchanges by the US War Department in 1907. Source: Henry A. Rucker (Collector of Internal Revenue) v. The Coca-Cola Company, U. Circuit Court, District of Georgia (Trial and Appeal Record, Federal Records Center, East Point, Georgia). The company later sued the government and the tax payments were returned (Allen, 1994, p. 43).

${ }^{9}$ Candler agreed to switch to granulated sugar after learning that he was paying freight on the moisture.

${ }^{10}$ Source: United State v. Forty Barrels and Twenty Kegs of Coca-Cola, 241 U.S. 265, 289, record of appeal from the Federal Records Center, East Point, Georgia.

${ }^{11}$ Beets can be grown in more regions than cane sugar and, thus, by switching to it the Company hoped to maintain a more continuous supply of Coca-Cola.
} 
the use of a small amount of saccharine in place of sugar. In a letter to his accountant, Woodruff acknowledged his hesitation: "Of course you know I am very leery about these things and much prefer not to do anything of the kind, except as a matter of life and death" ${ }^{\prime 2}$ (italics added). At that time there were also shortages of caffeine and coca leaves. Woodruff approved a temporary cutback in the amount of those ingredients as well. There is no evidence, however, that customers perceived a change in flavor. Even if all seven episodes are interpreted as quality changes, they exhaust the more than 70 years that we study - less than one change per decade.

Price and quality rigidities are noteworthy only relative to changing market conditions. The years 1886-1959 featured numerous shocks affecting the soft drink market. During the Spanish-American War a tax was imposed on patent medicines and Coca-Cola deemed liable for $1 / 8 \varnothing$ on every nickel drink (Riley, 1942, p. 26). There were also the demand-side shocks of Prohibition in 1920 and its repeal in 1933. The repeal occurred during the Great Depression, another large demand shock. The Company also faced prolonged investigation under the Pure Food and Drug Act of $1906 .^{13}$

To stress the importance of the changing economic conditions for the Coca-Cola Company, we focus on (i) changes in marginal materials costs and (ii) shortages of materials induced by regulatory interventions (government rationing). The most important material input was sugar. (By volume Coca-Cola is over 10\% sugar.) Materials generally were important components of costs.

From 1879 to 1955 , materials costs were between $30 \%$ and $50 \%$ of soft drink industry production value (Table 1). In 1920 the price of sugar was about \$0.10/lb (Allen, 1994, p. 104). The Company was using about 100 million pounds of sugar annually (The Coca-

\footnotetext{
${ }^{12}$ Source: Robert W. Woodruff in a letter to Arthur Acklin, October 2, 1942, Robert W. Woodruff Papers, Special Collections Section, Emory University Library.

${ }^{13}$ For a comprehensive list of changes in market conditions see Levy and Young (2004, pp. 771-773).
} 
Cola Company, 1925), and 1920 sales were about \$32 million (Annual Report, 1921). This puts sugar costs alone in 1920 at $31 \%$ of sales. Compare this to Coca-Cola's advertising expenditures share of sales (Table 1; column 3), which ranged between $8 \%$ and $17 \%$.

<<COMP: Place Table 1 about here>>

The importance of materials costs generally, and sugar costs specifically, lends perspective to several shocks weathered by the Coca-Cola Company. For example, in 1917 WWI sugar rationing was imposed. In May of that year, sugar sold for \$0.08/lb., up from an average of $\$ 0.05$ that had held over many years (Pendergrast, 1993, p. 129). This was a $60 \%$ increase for an input constituting at least one third of costs. (Around the same time, the Company experienced shortages of caffeine and caramel as well.) Then late in 1919 the price of sugar reached $\$ 0.16$ and sugar purchases were about $67 \%$ of Coca-Cola revenues (Allen, 1994, p. 104). ${ }^{14}$ There would have been relief from high sugar costs following WWI except for Howard Candler's ill-advised stockpiling of sugar. By 1921, Coca-Cola had warehouses full of contracted sugar while the market price was $3 \phi / l b$ (Fortune, 1951).

Sugar rationing was reenacted during WWII. At the worst point, producers were rationed 50\% of their prewar levels (Pendergrast, 1993, p. 201). ${ }^{15}$ There were also "shortages of crowns, bottles, cases, gasoline, trucks, equipment, [and] manpower" (Riley, 1942, p. 86). At the onset of WWII, the price of sugar was $\$ 0.02 / 1$ b. By the end of

\footnotetext{
${ }^{14}$ Interestingly, there is no evidence of Coca-Cola retail prices adjusting upward during WWI when its production costs soared, although during the postwar inflation there were isolated reports of retailers charging $6 \notin$ or $7 \notin$ for a Coke. Note that the Coca-Cola Company had no direct/legal control over the price that retailers charged. Levy and Young (2004, pp. 774-777) describe in detail some of the methods and techniques the Company used to "convince" the retailers that the nickel price was in their advantage.

${ }^{15}$ Allen (1994, p. 251) states that the number was 80 percent of prewar levels.
} 
WWII, the price was $\$ 0.08$, up by $300 \%$ (Allen, 1994, p. 276). ${ }^{16}$

Ultimately, it would be postwar inflation rather than any specific input cost that led to the demise of the nickel Coke. By the late 1940s, with production costs soaring, a handful of bottlers began charging the retailers $90 \phi-\$ 1.00 /$ case, up from $80 \notin .{ }^{17}$ In response some retailers raised the price. Time (1950b, p. 12) observed that, "In New York City, bottled Coca-Cola broke loose from its nickel moorings and for the first time went to $6 \notin$." Still, in 1950 only 125 of the 1,100 bottlers had initiated price increases to retailers. In 1951, when about $33 \%$ of bottlers had increased their traditional $\$ 0.80 /$ case wholesale price, Coca-Cola dropped the placing of " $5 \varnothing "$ in its advertising material. ${ }^{18}$ In 1955 , Business Week $(1955$, p. 44$)$ reported that a "bottle of Coke today sells for $6 \varnothing, 7 \varnothing$ or even $10 \varnothing$ depending on the area." ${ }^{19}$ By 1959 the last of the nickel cokes was gone.

\section{Implicit Contracts}

Implicit contracts are "arrangements that are not legally binding but that give both sides incentives to maintain the relationship" (Okun, 1981, pp. 49-50). ${ }^{20}$ We argue that an implicit contract guaranteed a constant nominal price and quality of Coca-Cola and that the consumers valued this guarantee.

\subsection{Economic Rationales for Implicit Contracts}

Sellers and buyers may enter into implicit contracts for various reasons. First, consumers

\footnotetext{
${ }^{16}$ WWII shortages led to temporary use of sugar substitute and decreases in caffeine and coca contents.

${ }^{17}$ Source: The Coca-Cola Company, Fact Sheet.

${ }^{18}$ Source: "Memorandum to: Mr. Nicholson" (Coca-Cola Company, January, 1951) and "The Price Situation" (Coca-Cola Company, February, 1951).

${ }^{19}$ As well, Coca-Cola began introducing various bottle sizes at various prices.

${ }^{20}$ Such informal agreements are termed "implicit," "self-enforcing," or "relational" (Gil and Marion, 2012). For example, Telser (1980, p. 27) refers to a "self-enforcing agreement" as one that "remains in force as long as each party believes himself to be better off by continuing the agreement than he would be by ending it." Baker, et al. (2002, p. 39) refer to "relational contracts: informal agreements and unwritten codes of conduct that powerfully affect the behaviors of individuals within firms."
} 
may value the guarantee of a fair price. ${ }^{21}$ There is evidence that fair prices are important to buyers. Kahneman, et al. (1986) provide survey evidence that the perceived fairness of prices is important for understanding consumer demand. In lab experiments, buyers often boycott, against their self-interest, sellers engaged in unfair price increases. ${ }^{22}$

Implicit contracts may mitigate time consistency problems in case of habit-forming goods. Sellers may attract consumers today by promising (a continuation of) low prices in the future, which can lead to dynamic inconsistency because when the future comes, firms have an incentive to raise prices (Nakamura and Steinsson, 2011). Consumers anticipate that by then they will be "hooked" and that refraining from paying the high prices will be difficult. While explicitly contracting on future prices with individual consumers may be prohibitively costly, entering into an implicit contract with all consumers facilitates transactions in the presence of this moral hazard.

Firms may also form implicit contracts to increase brand loyalty. Given ostensibly close substitutes, a firm's brand may convey information about hard-to-observe, but distinctive, characteristics of the good (or the "experience" of buying it from the particular firm) that differentiate it from similar goods (Telser, 1980; Klein and Leffler, 1981; Shapiro, 1983). Such hard-to-observe features create moral hazard problems. A brand's reputation can signal that the firm is indeed providing those characteristics. The brand then "corresponds to an implicit contract between seller and buyers whereby the former supplies high-quality experience goods" Cabral (2000, p. 659).

A firm's brand may also insure consumers against pass-through of input cost fluctuations. Consumers may be hesitant to commit to one good exclusively if there are

\footnotetext{
${ }^{21}$ Rotemberg (2011) develops the idea of a fair price in a model where consumers interpret price changes according to their fairness and react accordingly. In Ball and Romer's (2003) model, prices serve as a signal in a long-term relationship setting between consumers and producers, leading to infrequent price adjustments. Bils (1989) models a customer market where customers develop an attachment to a product.

${ }^{22}$ See Fehr and Gächter (2000), Levy, et al. (2002), Tyran and Engelmann (2005), and Gächter and Herrmann (2009).
} 
close substitutes. If input costs' fluctuations are passed on in the form of price

fluctuations, consumers might diversify across goods. ${ }^{23}$ However, consumers may be willing to commit exclusively if a firm stakes its brand (its goodwill). An implicit

contract is a credible commitment mechanism through which a firm can deliberately

make itself vulnerable to consumer backlash if pass-through occurs. ${ }^{24}$

The discussion above assumes that consumers are fully informed about the price, or that price monitoring can be done at low cost, which seems reasonable given that CocaCola is a frequently bought small-ticket item. The inclusion of " $5 \not "$ in ads and promotional merchandise kept consumers aware of this "selling" price, making it difficult for retailers to charge a higher price without consumers noticing it.

\subsection{Coca-Cola as a Candidate Good for an Implicit Contract}

Based on the rationales discussed above we might expect the Coca-Cola Company to have formed an implicit contract with its consumers if Coca-Cola (1) was potentially habit-forming, (2) had ostensible close substitutes available while its distinctive attributes were difficult to observe, and (3) had relatively volatile input costs.

That Coca-Cola was potentially habit-forming seems plausible. Coca-Cola contained caffeine and, up until 1918, contained an even larger amount than it does today (Schaeffer and Bateman, 1985). ${ }^{25}$ Furthermore, up until 1903 Coca-Cola contained small amounts of cocaine. The addictive potency of either ingredient (in the included amounts)

\footnotetext{
${ }^{23}$ This would be particularly true for habit-forming goods where an initially undiversified consumption bundle will be costly to diversify ex post.

${ }^{24}$ As one anonymous reviewer noted, there is an interesting difference between implicit contracts in labor markets and the implicit contract documented here. In labor markets, implicit contracts are usually considered to protect two-sided relationship-specific investments. In the case product markets, only the relationship-specific investment of the consumer has to be protected.

${ }^{25}$ For a recent study of habit formation in the context of soft-drinks, see Zhen, et al. (2011).
} 
is debatable. Consumers, however, likely viewed Coca-Cola as habit-forming. ${ }^{26}$ This is suggested by the intense USDA scrutiny following the Pure Food and Drugs Act, as well as by a resolution passed by the American Bottlers' Protective Association (a trade association) opposing the sale of soft drinks with either ingredient. ${ }^{27}$

As to close substitutes, there was no shortage of Coca-Cola copycats. According to the Company ad in the May 17, 1916 Drug Trade Journal , "[a] dozen or more manufacturers of imitations of Coca-Cola were either put out of business or went out of business with the aid of the sheriff," 28 referring to the Company's efforts to defend its trademark against infringement from substitute producers. These efforts were not entirely successful as new copycats kept springing up. ${ }^{29}$ Indeed, both Pepsi Cola and Royal Crown Cola would market $12 \mathrm{oz}$ (rather than $6.5 \mathrm{oz}$ ) bottles for a nickel during the Depression (Pendergrast, 1993, p. 193). ${ }^{30}$ While they were identical to Coca-Cola in several easily observable ways (e.g., brown; carbonated; liquid; sweet), Coca-Cola arguably had distinct, but difficult to observe, attributes (e.g., costly and exotic ingredients such as

\footnotetext{
${ }^{26}$ According to Allen's (1994, p. 41) account, the buyers of Coca-Cola at soda fountains would often order the drink by asking the drugstore employee to give me "a dope" or "a shot in the arm." This is clearly suggestive of the popular attitudes and perceptions towards the drink's habit-forming properties.

${ }^{27}$ The long and highly publicized legal-battles in which the Coca-Cola Company was involved following the government's lawsuits, have led to a spread of the popular perceptions and accusations that the drink is habit forming. The spread of these views was further aided by numerous medical experts who believed that Coke had addictive characteristics. For example, according to Allen (1994, p. 45), Dr. J.P. Baird, who was the President of the Medical Association of Georgia, testified as the government witness during the 1901 lawsuit ("Cocaine Lawsuit 1) that "Coca-Cola definitely was habit-forming... Persons who take it freely, seem to become more or less dependent on it." In Chapter 2 titled "Dope," Allen (1994) offers a detailed account of how these popular perceptions and beliefs spread over time across the entire US. This despite the (ex-post) assessment (e.g., Benjamin, et al., 1991) that most of the scholarly evidence presented by both sides at these court hearings seem to have been poor science, and despite the fact that most of the final verdicts in these court-cases were in favor of the Coca-Cola Company.

${ }^{28}$ Reproduced in the Coca-Cola Company's Advertising Copy Collection, 1916-1919, Vol. 5, 000496 ARS.

${ }^{29}$ According to National Bottlers Gazette (January 5, 1917, The Coca-Cola Company Archive), the list of imitators grew to hundreds and included "Afri-Cola, Ameri-Cola, Ala-Cola, Bolama-Cola, Cafe-de-Ola, Carbo-Cola, Candy-Kola, Capa-Cola, Chero-Cola, Christo-Cola, Coke-Ola, Coo-EE-Cola, Curo-Cola, Grap-O-Cola, Its-A-Cola, Kaffir-Kola, Kaw-Kola, Kiss-Kola, Ko-Ca-Ama, Koca-Nola, Ko-Co-Lem-A, Kokola, Klu Ko Kolo, Loco Cola, Luna Cola, Mitch-O-Cola, Mo-Cola, My Cola, Roco-Cola, Toca-Cola, Taka-Cola, Qua-Kola, Uneeda-Cola, Zero-Cola, and Zippi-Cola.” Allen (1994, p. 73) lists these "counterfeit" manufacturers and offers more details about the Company's efforts to fight them.

30 "Twice as much for a nickel too, Pepsi-Cola is the drink for you." This line is from a popular 1939 Pepsi jingle that played on radio.
} 
coca leaves and kola nuts; consistent manufacturing and bottling practices), and perhaps not less important, the cult of the Secret Formula.

Finally, while it is difficult to assess Coca-Cola production cost volatility relative to other consumer goods, we know that sugar accounted for about a third of total costs. Sugar was subject to shortages, rationing, and large price fluctuations during both World Wars. Furthermore, just like an undiversified portfolio, the fact that one commodity constituted a full third of costs lends itself to higher potential cost volatility.

\subsection{The Coca-Cola Company's Recognition of Consumer Concerns}

We argue above that Coca-Cola possessed characteristics associated with implicit contract goods. However, it was the Coca-Cola Company that formed an implicit contract with its consumers. The firm's perceptions of these characteristics and of consumers' concerns for these characteristics may be most important in this regard.

Despite the existence of close substitutes, the Company believed its product was distinctive in important but not immediately observable ways. For example, the Company preached to its employees about the drink's uniqueness in being of a "standardized" quality. In Reviewing a "Proud History:" 1886 to 1925 (a series of bulletins distributed to regional and district managers, salesmen and other employees) the Company stated that as early as 1887 "important progress was made in standardizing the drink [with the result that] today every Coca-Cola is like every other Coca-Cola." Furthermore, the Company perceived this as being important to consumers: "A citizen of Georgia may go to any other state, order a Coca-Cola [and] exclaim, 'Here's an old friend!'” Another bulletin crowed that, "[m]ore than 600 trade-marked drinks have appeared on the market during the life of Coca-Cola only to disappear [...] because "it repeats"' (italics added).

The two longest-serving Company presidents during 1886-1959 were convinced of 
the Secret Formula's importance to consumers. In 1899, amidst charges of cocaine content, about 20 salesmen, home office personnel, and branch managers met with Asa Candler (president, 1888-1916). Someone suggested: “Couldn't we just take out the cocaine?" Candler's response: "So you want me to change the formula of the country's favorite beverage[?] Never! There is nothing wrong with Coca-Cola. If there was anything the matter with it, do you think we would have such a problem keeping everyone supplied with it?” (Candler, 1950). Robert Woodruff (president, 1923-1939) later expressed his reluctance to change the Formula "except as a matter of life and death" (italics added).

Turning to input costs, the Company knew that they were volatile. However, did the Company believe that consumers wanted insurance against cost fluctuations? We again draw insight from the Reviewing a "Proud History" bulletins: "We are one of the few manufacturers in the [US] who adheres strictly and at all times to a one price policy. [...] This is a policy of fair dealing - it begets good will if you sell it to the trade so that it is understood." Also, consider a Company insert in a 1916 Drug Trade Journal: "Some said: 'Raise the price to the retailer.' [...] That is the summary of advice we have received during the past year from people who knew how greatly our cost of making Coca-Cola has been advanced [....] [W]e would be mighty poor specimens if we tried to make the druggist carry the load of our increased costs by cutting down your profits[....] The burden is ours-we have gladly assumed it." 31 The Company's unwillingness to pass cost fluctuations to retailers can be interpreted as an indicator of the Company's efforts to prevent the cost fluctuations from, in turn, being passed onto consumers.

Documenting whether or not the Company perceived Coca-Cola to be addictive is

\footnotetext{
${ }^{31}$ Reproduced in Coca-Cola Company’s Advertising Copy Collection, 1916-1919, Vol. 5, 00502 ARS.
} 
more challenging. ${ }^{32}$ The Company would never put that in writing. ${ }^{33}$ However, the Company's efforts during WWII to provide soldiers with Coca-Cola—and the responses from the soldiers - are telling. American GIs wrote home from European battlefields with near-worshipful descriptions of the drink: e.g., "You probably will think that your son has had his head exposed to the sun too long [but] three of us guys walked ten miles to buy a case of Coca-Cola, then carried it back. You will never know how good it tasted" (Pendergrast, 1993, pp. 210-211). ${ }^{34}$ Woodruff made a pledge: Coke would be made available to every member of the armed forces at a nickel (Kahn, 1969, p. 84). Company agents even sold nickels (at cost) so that soldiers could buy Coca-Cola in their accustomed manner (Coca-Cola Bottler, 1944, p. 35). This could not have been profitable in the short run. It is consistent with the Company perceiving its product as habit-forming and insuring its consumers against supply fluctuations.

\subsection{Observable Implications of Implicit Contracts}

If Coca-Cola is a good candidate product for an implicit contract, and the Coca-Cola Company recognized this, then the observable implications would include:

- evidence of the Company having communicated a pledge to consumers;

- $\quad$ since it could not set the retail price directly, evidence that the Company communicated the pledge and its profitability to retailers;

- evidence that the Company perceived itself as vulnerable to costly (in terms of

\footnotetext{
${ }^{32}$ According to Allen (1994, p. 53), Asa Candler used to encourage subtly spreading the idea that CocaCola contained cocaine.

${ }^{33}$ For example, it is not implausible that Candler's resistance to removing cocaine from the drink was in part indicative of his belief that doing so would no longer allow Coca-Cola to "hook" its customers. Furthermore, after winning an extended legal battle (1898-1902) to have Coca-Cola not taxed as a proprietary medicine, Company executives would be especially hesitant to establish what could amount to providing evidence of Coca-Cola attributes associated with medicines.

${ }^{34}$ Another soldier wrote: "[O]ne real bottle of Coca-Cola, the first one I have seen here. It was pulled out from under the shirt of a pilot. [...] He caressed it, his eyes rolled over it, he smacked his lips at the prospect of tasting it. I offered him one dollar for half of it, then two, then three, and five dollars."
} 
goodwill) backlash by reneging on the pledge;

- evidence of "renegotiations"- the Company's efforts to mitigate the goodwill costs by explaining the necessity of breaking the contract.

\section{Evidence of an Implicit Contract in the Case of Coca-Cola}

Next, we present evidence that Coca-Cola's fixed nominal price and quality were part of an implicit contract between the Coca-Cola Company and its consumers. This evidence consists of advertisements, trade journal inserts, and the Company's internal documents.

\subsection{Extending the Invisible Handshake to Consumers: Communicating the Pledge}

A remarkable feature of this implicit contract is that the Company made it explicit in the written guarantees and assurances of millions of print ads, displays, promotional giveaway items, etc. Moreover, assurances of quality and price were often included together. The guarantee of a constant price appears to have been a "clause" of the implicit contract from early on; that of constant quality seems to have evolved later on.

<<COMP: Place Table 2 about here >>

An alternative interpretation of such advertising materials is that they simply included the price, which happened to be $5 \not$. However, many of these advertising materials were durable items (e.g., metal signs, metal serving trays, etc.).Table 2 lists the advertising material distributed just in 1913. Such materials were offered to retailers to entice more purchases. Additionally, the Company would offer to paint retailers' buildings with large Coca-Cola murals providing 700 such paintings in 1925,820 in 1926 , and 835 in $1927 .^{35}$ Given the prominence of " $5 \notin$ " on many of these materials, their value as advertising for

\footnotetext{
${ }^{35}$ Source: "The Coca-Cola Company: Advertising Expenditures," Coca-Cola Company archives.
} 
the Company would likely depreciate (or even turn negative) in the event of the nickel price's disappearance.

Moving to some examples that span the period 1886-1959, first consider a 1898 ad (Atlanta Police Department Bulletin, 1898), when Coca-Cola was sold only in Atlanta. At any Atlanta fountain, the ad promised Coca-Cola at "5 cents per Glass." Also, besides claiming that it "Relieves Headache Immediately," the ad guaranteed the drink to be "Delicious! [and] Refreshing!" This was certainly not a constant quality guarantee, but it began a theme that would later evolve into such a guarantee. In a 1903 ad (Atlanta Journal, 1903), the Company touted that it was now both "At Soda Fountains and Carbonated in Bottles." In either case, it was still "5 CENTS." Ads with similar promises appeared in a 1909 Atlanta Constitution. For over a decade, Atlanta consumers were promised Coca-Cola for $5 \varnothing$ in the bottle or at the fountain.

Coca-Cola did not remain local to Atlanta for long. A 1906 full-page Cosmopolitan ad promised it to the entire nation, for " $5 \varnothing "$ and "AT ALL FOUNTS AND IN BOTTLES." Similar 1906 ads ran in American Theater and Country Life in America. Ironically, given the court battles that followed, the Company also ran ads in 1906 stating that it was "GUARANTEED UNDER THE PURE FOOD AND DRUG ACT." ${ }^{36}$ Despite later problems with the USDA, the theme of "guaranteeing purity" became recurrent.

In the early 1900s Coca-Cola faced competition from a myriad of imitators who tried hard to be perceived as close substitutes by consumers. By 1908 the Company was encouraging consumers to "GET THE GENUINE" Coca-Cola. ${ }^{37}$ Also, 1912 Coca-Cola ads warned "BEWARE!!! of Imitations" and encouraged consumers to "Demand the Genuine - Refuse Substitutes." ${ }^{38}$ Competition with imitators and the purity guarantee

\footnotetext{
${ }^{36}$ Source: The Coca-Cola Company, "Guaranteed."

${ }^{37}$ July $16^{\text {th }}$, 1908 issue of Life; the ad also guaranteed that Coca-Cola was " $5 \not$. Everywhere."

${ }^{38}$ Source: Advertising Copy Collection, 00349 ARS.
} 
complemented each other in an evolving theme of constant quality in the Company's advertising.

During the 1920s Coca-Cola continued to stress the " $5 \varnothing "$ price, as in a full-page 1922 ad in The Ladies Home Journal. Then the 1930s witnessed the introduction of the famous "pause that refreshes" slogan. ${ }^{39}$ The "pause" had by then been part of consumers' lives for over 50 years; it was "the best friend thirst ever had." The Company stressed a familiarity that would also feed into the evolving theme of constant quality.

In 1941 issues of National Geographic, Boys' Life, Collier's, Life, Time, and the Saturday Evening Post, the "pause that refreshes" was still promised at "5ф," but now there was an additional claim: "You trust its quality." ${ }^{40}$ And in a 1942 Saturday Evening Post the "5ф" and "Delicious and Refreshing" Coca-Cola stated that "Quality carries on." The guarantee of quality was prominent and the "carries on" implied a commitment to continuity over time. By 1945, during WWII sugar shortages and the resulting sugar rationing, the Coca-Cola Company evoked this guarantee to explain Coca-Cola shortages to civilian consumers. "Where's all the Coke gone, anyway?" asked one ad:

[T]he answer is: there's a world-wide sugar shortage, caused by worldwide disorder and confusion that goes along with war. Sugar shortage means Coke shortage because Coca-Cola never compromises on quality. Today, yesterday, tomorrow-Coca-Cola means Coca-Cola, the same quality as always [our emphasis]. ${ }^{41}$

Such ads still stated "5ф," but now the guarantee of constant quality became explicit. ${ }^{42}$

\footnotetext{
${ }^{39}$ See, for example, Nation's Business (1938).

${ }^{40}$ Source: Advertising Copy Collection, 01625 ARS.

${ }^{41}$ Source: Advertisement No. S-3. Another ad featured a neighborhood store clerk telling consumers, "Sorry, but we're short on Coke today." Consumers are encouraged not to blame the clerk because, again, the sugar is being rationed and "there's one thing you can always be sure of - the Coke you get is the real thing [and] the same quality you have always known [our emphasis]." Source: Advertisement No. S-2.

${ }^{42}$ Note that the Coca-Cola Company substituted a small amount of saccharine for sugar and also temporarily reduced the caffeine content at this time. However, president Woodruff was very reluctant to
} 
These examples come from print ads because they are the most readily available as facsimiles at the Coca-Cola archives. However, the Company was issuing similar pledges on its durable promotional items (Table 2). Already in 1887 the Company was distributing 45 tin signs and oil cloth hangers (Allen, 1994, p. 30). By the early 1920s these materials included 50,000 metal serving trays and 100,000 streetcar signs (Allen, 1994, pp. 167-168). In 1924 the Company "maintained more than 20,000 painted walls and bulletins throughout the United States" and by the 1930s it also maintained 160,000 billboards across the US (Allen, 1994, p. 206). ${ }^{43}$ These materials continued to remind customers that Coca-Cola still sold for a nickel, while its "quality carries on."

\subsection{Informing and Convincing Retailers}

The Coca-Cola Company also made efforts to inform retailers that it had made an implicit contract with consumers and that it was in their common interest not to break it. In a 1916 Drug Trade Journal insert during WWI, the Coca-Cola Company told retailers that "Price, quality and advertising will remain the same" and stated: "All we ask of our dealers is the natural and human reciprocity of serving only the genuine and serving it properly." Presumably, in asking for retailers to "serve it properly," the Company referred to $6.5 \mathrm{oz}$ at $5 \varnothing$, using unadulterated syrup.

By the 1920s the Company was using trade journal inserts to stress the standard $6.5 \mathrm{oz}$ and $5 \varnothing$ price as something expected by consumers and profitable to retailers. "This Glass increases sales," stated a 1923 insert referring to $6.5 \mathrm{oz}$ glasses that could be "bought in

make these changes: "I am very leary[;] and much prefer not to do anything of the kind, except as a matter of life and death" (Source: Robert W. Woodruff in a letter to Arthur Acklin, October 2, 1942, Robert W. Woodruff Papers, Special Collections Section, Emory University Library). Since we find no evidence that customers perceived a change in flavor, we suspect that the Coca-Cola Company believed that it had succeeded in keeping quality as constant as its constraints would allow. In making the guarantee of constant quality explicit at this time, the Company also positioned itself so that it was vulnerable to backlash.

${ }^{43}$ Source: Turner Jones of the Coca-Cola Company quoted in a letter dated March 14, 1940 from Lloyd Paul Stryker to John M. Drescher of the D’Arcy Advertising Company. 
quantity from your jobber." The insert referred to "The Right Price" of "5ф" which "is the price people expect to pay for Coca-Cola, because it is established by years of custom"

[our emphasis]. As well, "it gives you [the retailer] a good profit on every sale, but it gives you most profit by giving you more sales [and it's] the price that keeps your cash register ringing, and that's the music that builds business." 44

By the 1940s efforts to convince retailers of the profitability of Coca-Cola at $5 \not$ price became even more pronounced. "LOOK AT IT THIS WAY," requested a 1942 insert featuring a magnifying glass focused on a nickel: "Coca-Cola magnifies the nickel to real importance in your store." ${ }^{45}$ Another 1942 insert states the Company's guarantee to retailers: "We make this pledge to YOU[.] In national magazines, in newspapers, on posters, and over the radio, we're telling the world that the unmatched quality of CocaCola remains the same even though the quantity is limited by Government order"46 (italics added). All of these inserts explicitly contained " $5 \not "$ and may also be viewed as a veiled warning to retailers not to charge more, an effort at retail price maintenance. ${ }^{47}$

As late as 1950 an insert in Food World touted the explicit pledge: "Continuous Quality" and "Continuous Price." 48

\subsection{Did the Coca-Cola Company Perceive Itself as Vulnerable to Backlash?}

In 1948, Robert Woodruff received an editorial in the mail written by Duke Merritt of the

\footnotetext{
${ }^{44}$ Source: Trade Paper Insert, reproduced, Coca-Cola Company Archive. Also, in Reviewing "A Proud History" 1886 to 1925 . Every page included, in the lower margin, an underlying theme: "Use the Retailer's figures to show him the profit on Coca-Cola [and] Show him how to push sales to increase the profit[.]" Retailers needed to know that "It is not the $5 \varnothing$ so much as it is the 2,400,000,000 drinks per year. . . It is this volume which enables us to offer the public, at a nickel, an absolutely pure soft drink" (p. 1900).

${ }^{45}$ It continues: "When you look at Coca-Cola in terms of what you sell in a year, you see a big profit from a $5 \not$ sale. On the sale of a case a day your gross profit is $\$ 125.00$ a year. How's that for magnifying the value of a nickel?"

${ }^{46}$ Source: Advertising Copy Collection, "Chain Store Age."

${ }^{47}$ Concerning quality, yet another 1942 insert declared: "QUALITY . . . the quality of genuine goodness. That's what your customers recognize in Coca-Cola. . . 5 5. You trust its quality." Source: Advertising Copy Collection, 01724 ARS. Many of the promotional items listed in Table 2 also had "5ф" imprinted on them. See Munsey (1972) for numerous examples of such promotional items of different types.

${ }^{48}$ Source: Advertising Copy Collection, 02815 ARS.
} 
Cartersville, Georgia Daily Tribune. The editorial was written by Merritt "in appreciation of the fact that Coca-Cola is the one unchanged friend of childhood, still the same good taste at the same nickel price". ${ }^{49}$ The editorial stated:

"[W]ay back yonder, a loaf of bread was a nickel, soap was a nickel . . and coffee and milk were a nickel each [and even] beer, was also five cents a glass then. . Coca-Cola has changed neither its price nor its quality. . . Look what has happened to other five-cent items in CocaCola's nickel life time. Bread is 15 cents a loaf, in most places, soap is 10 and 15 cents a cake, coffee and milk each cost a dime ... and beer is 30 cents, we hear. But our old friend Coca-Cola still remains the same, merely five cents."

Woodruff personally replied to Merritt: "Your comment regarding our product and our Company describes exactly what has been our desire[.]"

". . In the recent era of rationing and the subsequent period of high — and rising - costs, the maintenance of the $5 \varnothing$ price has not been devoid of difficulty, but the compensations that arise from doing so, as exemplified by your friendly remarks, are many and not the least of them is the good will embodied in such expressions as these in your editorial" [our emphasis]. ${ }^{50}$

\footnotetext{
${ }^{49}$ Source: Robert W. Woodruff Papers, Coll. 10, Box 124.

${ }^{50}$ The Company preserved copies of numerous editorials and articles expressing similar sentiments. For example, in the December 28, 1947 Sunday Booster (Lincoln-Belmont area of Chicago), Leo Lerner wrote: "No doubt you have noticed the new look in the grocery stores? [sic] It's on the price tags. The day my wife sent me shopping ... I asked the proprietor if there was anything else in the store [besides Coca-Cola] that had not risen in price. . . [H] e shook his head, melancholy as he could be. 'Nope,' said the grocer. 'Coke is the only thing in the whole place that hasn't gone up in price'. . I stuffed the groceries I bought for $\$ 3$ into my overcoat pocket and went out. On the way I tipped my hat to the Coca-Cola." And an editorial from a 1946 Worthington Globe (Worthington, Minnesota) lashed out at individual retailers that deviated from the $5 \notin$ standard: "[S]ome local firms have selected for a price upping the very commodity that will discredit all these reassuring words and action - the lowly 'Coke'... [Here] come a bunch of local pirates before the clods are dry on OPA's grave, who would take Coca-Cola out of the mouths of ordinary common people and make a dime drink of it - nectar for blue bloods to drink. And this without a cent increase in the
} 
Having communicated the pledge of constant price and quality to consumers and retailers, Woodruff seems to have felt that the Company's goodwill was structured in a way that left it vulnerable to a costly backlash in the event of breach of the implicit contract.

This is supported by the Company's issue of an (undated) set of "Instructions for Salesmen in Campaign for Promoting 5 $\varnothing$ Price on Coca-Cola.” In it the writer ponders: "how would one-third of your fountain customers feel if they were required to pay $100 \%$ more [than] they had been accustomed to paying, or that they felt was right for them to pay[?]" [our emphasis]..$^{51}$ The document also claims what may be an implicit acknowledgement that new consumers were concerned with future price fluctuations: holding to the nickel price "attracts youth - your customers today and tomorrow."

In 1948, vice president Ralph Hayes wrote to president William Hobbs on the importance of maintaining the nickel price: "our bottlers should realize increasingly that they are not only in the process of effectuating a monumental merchandising achievement but that the press and public hold them in high esteem for the vision and the courage so far shown." Fellow executive and future president H. Burke Nicholson then circulated that letter widely throughout the company stating that nickel price maintenance was "a basic problem of vital interest to our entire organization."

Documents from 1950, when inflation made the nickel Coke increasingly untenable, offer the clearest evidence that the Coca-Cola Company perceived itself as vulnerable to loss of goodwill. A representative of the Coca-Cola Bottling Company wrote to Eugene

wholesale price. Fie on them! May their cash registers tarnish in a pause that will refresh their memories of a mutual pledge taken to 'hold the line' and combat inflation!"

${ }^{51}$ The writer makes an interesting exception for "outlets such as night-clubs [and] cocktail lounges" where enforcing the $5 \notin$ price was not thought to be as important "since the customer expects to pay a premium." 
Kelly, head of international operations, concerning the "price situation:"

"[A]ll of the facts and figures that we have [...] tend to point out the pitfalls and the possibility of difficulty on the long term basis, particularly have we pointed out the possible public reaction such as that which you know about in connection with Standard Stations, who changed over some 600 of their machines to $10 \notin$ slots and because of public reaction reduced the price to $5 \varnothing$ recently."

The Company, fearful of the backlash as retailers abandoned the nickel, hired a consulting firm to conduct a survey of retail prices and consumer reaction to price increases in 27 towns. ${ }^{53}$

Almost all of the Company documents we located focus on the costs of changing the nickel price. What is not found in the internal documents is also notable: any reference at all to altering the Secret Formula or serving size. Recall that both dominant personalities in Coca-Cola's early history_-Asa Candler and Robert Woodruff_established that changing the Secret Formula was not on the table. ${ }^{54}$ It would have made little sense to elaborate upon the costs of doing something that was essentially taboo.

\subsection{Renegotiations}

The Coca-Cola Company eventually recognized that the nominal nickel price was inconsistent with the realities of the post-WWII inflationary economy. We find some

\footnotetext{
${ }^{52}$ Despite his primary role in international operations, the letter refers entirely to US operations and was copied to President H. Burke Nicholson.

${ }^{53}$ Source: Memorandum dated November 7, 1950 from John Toigo, D’Arcy Advertising Company, to H. Burke Nicholson. We located the summary results of one such survey (for Alexandria, LA) in the CocaCola Archives that described "swift public reaction:" "At first, the public bought up all available CocaCola at the old price. As soon as the supply was depleted, [a] boycott was imposed." The summary reported several "typical consumer comments" including: "Buy a Coke? Not me. Haven't had one since the price went up. I'll wait until it comes down." "They will be sorry. I haven't had a Coke all week and I won't until it sells for a nickel." "The bastards! No one buys Coke now." "Coke will be back to a nickel soon. Just wait and see."

${ }^{54}$ Kahn (1969, p. 74) notes that Woodruff, upon becoming president of Coca-Cola, "established several guidelines [among which was that] he would never tamper with the quality of the product."
} 
evidence that around 1950 the Company contemplated a "renegotiation" of the implicit contract with consumers. ${ }^{55}$ For example, a 1950 letter from John Toigo of the Company's primary advertising firm, D’Arcy, to vice president H. B. Nicholson, suggests: “[W]hen a bottler raises a price complete merchandising and advertising programs might be furnished to him so that a proper price level at which the product should sell at retail could be quickly established, just as against $80 \notin$ we established the nickel price." ${ }^{, 56}$

Less than one month later a "Coca-Cola Price Study" based on 38 towns nationwide was circulated inside the Company. ${ }^{57}$ One of the suggestions based on the findings: if a bottler raised its price then the "bottler should be prepared to fully advertise and merchandise suggested new [retail] price levels[,] as assiduously as we have the $5 \varnothing$ and $25 \varnothing[$ six packs] prices under the old price structure."

These proposals can be interpreted as plans to renegotiate standard prices for CocaCola. We find no evidence that such plans were pursued, but the fact that they were seriously contemplated is itself evidence in favor of an implicit contract's existence.

\section{Relationship between the Implicit and Explicit Contracts}

In 1899 the Coca-Cola Company signed over bottling rights for most of the US to Tennessee lawyers, Benjamin Thomas and Joseph Whitehead. ${ }^{58}$ They could purchase syrup from the Company at 92ф/gallon in perpetuity. In Levy and Young (2004, pp. 778782) we argue that a constant retail price could be optimal if Coca-Cola acted like a monopoly in a particular stage of processing where the price of its own output (syrup)

\footnotetext{
${ }^{55}$ In a previous version of this paper, we also argued that the backlash associated with the introduction of "New Coke" in 1985 was evidence of the quality clause and its importance to consumers. The Bottler's incurred a direct loss of $\$ 30$ million in the form of unsold New Coke inventories according to the Atlanta Journal and Constitution (1995) and Collins (1995). In that case, the hasty (re)introduction of "Coca-Cola Classic" represented attempts of renegotiations.

${ }^{56}$ Source: Letter from John Toigo, D’Arcy Advertising Company, to H. B. Nicholson, November 6, 1950.

${ }^{57}$ Source: "Coca-Cola Price Study," an internal Coca-Cola Company document, dated December 4, 1950.

${ }^{58}$ Mississippi and New England had previously been contracted for by two separate individuals.
} 
was fixed. Here we are suggesting an alternative source of price rigidity. However, we believe that the two explanations are related: the contract with bottlers created incentives for the Company to develop and strengthen an implicit contract with its consumers.

In 1900 the original bottling company split into two regional "parent bottlers" (north and south US) that licensed bottling rights to smaller bottlers. Soon the Company was shipping syrup directly to the smaller bottlers. According to Allen (1994, p. 109), the parent bottlers "took a royalty on every gallon, even though they never handled a drop."

The contract was amended in 1901. The Company agreed to sell syrup to the parent bottlers at $\$ 0.90 /$ gallon plus a $\$ 0.10 /$ gallon rebate for advertising materials. ${ }^{59}$ In that form, the contract lasted until 1921. ${ }^{60}$ We know that Coca-Cola was the largest soft drink producer; it had market power based on its brand. Yet it acted as a price-taker for a 20year period. As long as its profit margin was positive, the Company's profits could increase only by increasing the quantity of syrup sold. The retailers and bottlers, however, were in principle able to exploit the Coca-Cola brand and raise the price on the differentiated product. It would then understandably be in the Company's interest to strip them of their price-setting ability. Forging an implicit contract with consumers - one that included the $5 \notin$ price — may have helped to accomplish this.

Of course, explicit evidence that Coca-Cola tried to deprive retailers and bottlers of price setting ability is hard to come by. As Fortune reported in 1951, "Coke has been charged with coercing its bottlers to stay at the 80 -cent case price, but the charge has never been even nearly substantiated." The Company seems to have understood the

\footnotetext{
${ }^{59}$ Source: Thomas Ben, letter to W.D. Boyce, November 15, 1901, "Benwood."

${ }^{60}$ In 1921 a new agreement was signed where the Company sold syrup to the parent bottlers at \$1.17/gallon plus, for every cent that a pound of sugar rose in excess of $7 \phi$, a $6 \phi$ premium (Pendergrast, 1993, p. 144). This contract remained unchanged through the demise of the nickel Coke (Johnson, 1987, p. 13).
} 
precarious position that such "coercion" could create a legal complication. ${ }^{61}$

\section{Alternative Explanations for the Episode}

In Levy and Young (2004, pp. 789-794) we carefully considered but ultimately ruled out several alternative explanations for the price rigidity of Coca-Cola. These included price points (Kashyap, 1995) and productivity growth that could offset unfavorable changes in market conditions. However, while our previous paper focuses on an explicit contract with bottlers and two "technological" factors, the present discussion of an implicit contract makes it worthwhile to consider two other alternative explanations.

\subsection{Investing in Brand (Stressing Quality) to Charge Premium Price}

A firm may use advertising as a means of product differentiation. Competitors tried to imitate Coca-Cola, believing that they could pass themselves off with similar names. In such settings, firms may use persuasive (rather than informative) advertising to shift consumer preferences and establish or strengthen brand loyalty (Carlton and Perloff, 2005; Bagwell 2007) to increase market power (Telser, 1964). Product differentiation leads to higher profits via higher demand and lower price elasticity, allowing for a premium price to be charged (Waldman and Jensen, 2001, p. 357). Persuasive advertising can also deter new entry by increasing the costs of inducing consumers to switch from established goods (Bagwell, 2007, p. 1715).

\footnotetext{
${ }^{61}$ For example, a 1947 legal department memo noted: “in Federal Trade Commission vs. Eastman Kodak [...] the Commission held that since Kodachrome film had only one source, price maintenance could not be protected." This memo was included with correspondence from Company vice-president Ralph Hayes concerning retail deviations from 5๕. Source Ralph Hayes, letter to W. J. Hobbs, December 9, 1946; attached, legal department memo dated January 9, 1947, "5ф Price for Coca-Cola." However, in the 1950 "Coca-Cola Price Study" a recommendation to bottlers was: "Coca-Cola should be sold as cheaply as possible consistent with profit," which might mean that as long as there's a positive profit margin for bottlers and retailers, keep the price at $5 \phi$; the Company will profit via volume. Also, in a somewhat comical letter drafted to bottlers (attached to an August 23, 1950 letter from vice president H. B. Nicholson to Pope Brock) after seven full pages presenting arguments why the bottler should hold the 80 cent per case wholesale price, on the eighth and final page it states: "In spite of the fact that our business and yours was built on the $80 \notin$ price, we have no sentimental attachment to it, and let me repeat, we have no desire to influence you to maintain it." It is unclear whether or not this letter was ever actually sent to bottlers.
} 
This explanation, however, is inconsistent with the Coca-Cola making the $5 \notin$ price a focal point of advertising. There is ample evidence that advertising containing price information increases the price elasticity of demand. ${ }^{62}$ It is also inconsistent with the Company's persistent resistance to retail price increases.

By promoting and pushing the $5 \varnothing$ price of Coke, the Company conditioned the public to perceive any price hike as unjustifiable. It created a point of extreme price elasticity, effectively limiting its own market power. Thus, the strategy of heavily promoting and committing to the nickel price would be inconsistent with a goal of increasing profits via product differentiation and a lower price elasticity of demand.

\subsection{Market Penetration through Lower Price}

Coca-Cola may have used an "introductory" low price in order to gain a foothold and capture market share by drawing customers from existing firms. In the marketing literature, it is well-known that a low introductory price often employed by entrant firms, creates product awareness and induces consumer trials (Urban and Houser, 1993).

However, a nickel price policy lasting over 7 decades is inconsistent with this explanation, although the Company undoubtedly pursued some forms of market penetration strategies early on. During 1889-1893, for example, it distributed "tickets" throughout the Atlanta area that, when presented at a fountain, entitled the holder to a complimentary Coca-Cola. This strategy was perceived as effective and subsequently expanded. From 1894 to 1913 , about 8.5 million coupons were redeemed by the Company. ${ }^{63}$

The nickel price, however, was not lower than the prices of similar products at that

\footnotetext{
${ }^{62}$ See, for example, a meta-study conducted by Kaul and Wittink (1995) who considered 18 studies covering a 20 -year period.

${ }^{63}$ As reflected on in Reviewing a Proud History: "We gave it to hundreds. They learned by doing. Now billions pay for it! 2,400,000,000 drinks a year!" Source: www.thecocacolacompany.com/heritage/pdf/cokelore/Heritage_CokeLore_cocacolasampling.pdf.
} 
time. For example, many soft drinks during the late 1800s, which at the time were often marketed as patent medicine, were selling for $5 \notin$. Other drinks, including beer, coffee, milk, etc., were also selling for a nickel. Indeed, Joseph Biedenharn, the first entrepreneur to successfully bottle Coca-Cola (in Mississippi in 1894), recollected in a 1959 issue of the Coca-Cola Bottler that "soda water bottlers didn't want to bother with it; besides, they, said, the price of Coca-Cola was too high" (Tedlow, 1990, p. 41). So, the initial pricing of the product does not appear to have been designed to undercut competitors.

More importantly, however, the Company's decision to stick to the nickel price even after becoming the dominant player in the market is inconsistent with this explanation. Recall that in 1945 the Coca-Cola Company had a 50 percent market share of the $\$ 579$ million bottled non-alcoholic carbonated beverage industry. Having achieved such dominance, one would expect that the Company would move away from the nickel price and raise it if it followed a market penetration strategy through an introductory low price. The company, however, maintained the nickel price for another 15 years.

\section{Conclusion: What Do We Learn from the Coca-Cola Case?}

We have documented a period of more than 70 years of price and quality rigidity for arguably the world's most widely recognized consumer good. Yet Coca-Cola is still only a single good. Does this case study have broader relevance? We believe it does.

First, it points towards a widespread phenomenon of "customary prices" in the late $19^{\text {th }}$ and early-to-middle $20^{\text {th }}$ century US. For example, many food items (e.g., a mug of beer, a cup of coffee, a loaf of bread, a pack of Wrigley's gum, a bar of Hershey's chocolate, etc.) also sold for a nickel for many years. As discussed in Levy and Young (2004), many US chain stores operating in that period (e.g., Woolworth, Kresge's (Kmart), etc.) were "Nickel" or "Five-and-Dime" stores, selling goods only for $5 \varnothing$ or $10 \varnothing$. 
Customary prices may be important for explaining why US nominal retail prices were more rigid historically during that period (e.g., Kackmeister, 2007) and implicit contracts may have played a role in their establishment. ${ }^{64}$

The Coca-Cola implicit contract episode highlights an extraordinarily successful firm that effectively chose to almost entirely forgo nominal price and quality adjustment. While the implications of costly price adjustment have been widely studied, analyses considering adjustment along other margins are rare. Danziger (2001) and Anderson and Toulemonde (2004) are examples; they consider firm behavior in the presence of both price and quantity adjustment costs. ${ }^{65}$ To our knowledge there are no analogous studies that also incorporate quality changes. The Coca-Cola case study highlights the need for empirical studies of costs of adjustment along these margins (e.g., Müller et al., 2007).

Finally, to our knowledge, this is the first study to offer direct evidence of an implicit contract in a consumer goods market. How prevalent are implicit contracts in such markets? This paper may serve as a guide to developing relevant testable hypotheses to identify such goods. It may also help to design surveys that identify implicit contracts, as in Blinder et al. (1988). Of course, this paper may also provide impetus to further narrative case studies.

\footnotetext{
${ }^{64}$ Young and Blue (2005) find that from 1938 to 1951 Bayer Aspirin, Gillette Blue Blades, and Tums Tablets had constant prices in Sears, Roebuck catalogs. KC Baking Powder sold at $25 \phi$ for over 50 years. Source: Grocer's Want Book, a pamphlet distributed by the Jaques Mfg. Co., Chicago, IL, the maker of the K.C. Baking Powder, to the retail grocers for managing and keeping track of their inventories (undated). ${ }^{65}$ Ginsburgh, et al. (1991) is an early example of a model of quantity adjustment costs that generates sticky prices similar to a menu cost model. In Levy and Snir (2013), firms decide whether to adjust prices or quantities based on the attention time-constrained shoppers pay to prices and quantities when they shop.
} 


\section{References}

\section{Publications}

Allen, Frederick. 1994. Secret Formula: How Brilliant Marketing and Relentless

Salesmanship Made Coca-Cola the Best-Known Product in the World. New York, NY: Harper Business.

Álvarez, Luis J., Emmanuel Dhyne, Marco Hoeberichts, Claudia Kwapil, Hervé Le Bihan, Patrick Lünnemann, Fernando Martins, Roberto Sabbatini, Harald Stahl, Philip Vermeulen, and Jouko Vilmunen. 2006. "Sticky Prices in the Euro Area." 4 Journal of the European Economic Association 575-584.

American Theater. June (1906). [Coca-Cola Company Archives.]

Anderson, Eric, Nir Jaimovich, and D. Simester. 2012. "Price Stickiness: Empirical Evidence of the Menu Cost Channel." Manuscript, Northwestern University.

Anderson, Eric and D. Simester. 2010. "Price Stickiness and Customer Antagonism." 125 Quarterly Journal of Economics 729-765.

Andersen, Torben and Eric Toulemonde. 2004. "Adapting Prices or Quantities in the Presence of Adjustment Costs?" 36 Journal of Money, Credit and Banking 17796.

Atlanta Constitution. 1909. October 26, 1909. [Coca-Cola Company Archives.]

— 1920. "Eight Cents a Glass: Coca-Cola Price Uniform 8 Cents at Founts Monday," April 18, 1920.

Atlanta Journal. 1903. November 22, 1903. [Coca-Cola Company Archives.] Atlanta Journal and Constitution. 1995. "New Coke's 10 ${ }^{\text {th }}$ Anniversary: From Catastrophe to a Classic," April 11, 1995. Atlanta Police Department Bulletin. 1898. p. 26. [Coca-Cola Company Archives.] 
Bagwell, Kyle. 2007. "The Economic Analysis of Advertising," in M. Armstrong and R. Porter, eds., Handbook of Industrial Organization, Volume 3. New York, NY: North Holland.

Baker, George, Robert Gibbons and Kevin J. Murphy. 2002. "Relational Contracts and the Theory of the Firm." 117 Quarterly Journal of Economics 39-84.

Ball, Laurence and David Romer. 2003. "Inflation and the Informativeness of Prices." 35 Journal of Money, Credit, and Banking 177-196.

Benjamin, Ludy T., Anne M. Rogers and Rosenbaum, Angela. 1991. "Coca-Cola, Caffeine, and Mental Deficiency: Harry Hollingworth and the Chattanooga Trial of 1911." 27 Journal of the History of the Behavioral Sciences 42-55.

Bils, Mark. 1989. "Pricing in a Customer Market.” 104 Quarterly Journal of Economics 699-718.

Bils, Mark and Peter Klenow. 2004. "Some Evidence on the Importance of Sticky Prices." 112 Journal of Political Economy 947-985.

Blinder, A.S., E.D. Canetti, D.E. Lebow and J.B. Rudd. 1988. Asking about Prices. New York, NY: Russell-Sage Foundation.

Business Week. 1955. "Coke: New Faces, New Bottles," February, 1955: 44-51.

Cabral, Luís, M. B. 2000. "Stretching Firm and Brand Reputation." 31 The RAND Journal of Economics 658-673.

Candler, Charles Howard. 1950. Asa Griggs Candler. Atlanta, GA: Emory University. Carlton, Dennis. 1986. "The Rigidity of Prices." 76 American Economic Review 637-58. Carlton, Dennis and Jeffrey Perloff. 2005. Modern Industrial Organization, $4^{\text {th }}$ Ed. Boston, MA: Pearson-Addison Wesley.

Cecchetti, Steven G. 1986. "The Frequency of Price Adjustment: A Study of Newsstand Prices of Magazines." 31 Journal of Econometrics 255-274. 
Chevalier, Judith and Anil Kashyap. 2011. "Best Prices." NBER Working Paper, No. 16680.

Daly, Herman E. 1970. "Some Observations on the Causes and Consequences of the Shortage of Change in Northeast Brazil." 78 Journal of Political Economy 18184.

Danziger, Leif. 2001. "Output and Welfare Effects of Inflation with Costly Price and Quantity Adjustments." 91 American Economic Review 1608-1620.

Dhyne, Emmanuel, Luis J. Álvarez, Hervé Le Bihan, Giovanni Veronese, Daniel Dias, Johannes Hoffmann, Nicole Jonker, Patrick Lünnemann, Fabio Rumler, and Jouko Vilmunen. 2006. "Price Changes in the Euro Area and the United States: Some Facts from Individual Consumer Price Data." 20 Journal of Economic Perspectives 171-192.

Collins, Glenn. 1995. "Ten Years Later, Coca-Cola Laughs at 'New Coke'." New York Times, (April 11, 1995): Business Day Section, p. C4.

Cosmopolitan. 1906. May. [Coca-Cola Company Archives.]

Country Life in America. 1906. June 6, 1906. [Coca-Cola Company Archives.]

Dutta, Shantanu, Mark Bergen and Daniel Levy. 2002. "Price Flexibility in Channels of Distribution: Evidence from Scanner Data." 26 Journal of Economic Dynamics and Control 1845-1900.

Dutta, Shantanu, Mark Bergen, Daniel Levy and Robert Venable. 1999. "Menu Costs, Posted Prices, and Multi-product Retailers.” 31 Journal of Money, Credit, and Banking 683-703.

Eckard, Woodrow E. 2007. "Retail Price Concentration, Transaction Costs, and Price Flexibility circa 1900.” 44 Explorations in Economic History 131-153. 
Eisenhower, Dwight D. 1951. Testimony Before Senate Subcommittee. Associated Press, February 2, 1951.

1943. Top Secret Cable, June 29, 1943, Emory University Central Library, Robert Woodruff Special Collection.

Emory Alumnus. 1932. [01137 ARS, Coca-Cola Company Archives.]

Fehr, E. and S. Gächter. 2000. "Fairness and Retaliation: The Economics of Reciprocity." 14 Journal of Economic Perspectives 159-181.

Fortune. 1951. "The Nickel Coke is Groggy," January, 1951: 78-79, 129-133.

Gächter, Simon and B. Herrmann. 2009. "Reciprocity, Culture, and Human Cooperation: Previous Insights and a New Cross-Cultural Experiment." 364 Philosophical Transactions of the Royal Society B - Biological Sciences 791-806.

Genesove, David. 2003. "The Nominal Rigidity of Apartment Rents." 85 Review of Economics and Statistics 844-853.

Gil, Ricard and Justin Marion. 2012. "Self-Enforcing Agreements and Relational Contracting: Evidence from California Highway Procurement.” 29 Journal of Law, Economics, and Organization 239-277.

Ginsburgh, Victor, Philippe Michael, and Philippe Moës. 1991. “Quantity Adjustment Costs and Price Stickiness." 36 Economics Letters 121-125.

Goldberg, Pinelopi and Rebecca Hellerstein. 2007. "Sticky Prices: Why Firms Hesitate to Adjust the Price of Their Goods." 13 Current Issues in Economics and Finance $1-7$.

— 2013. "A Structural Approach to Identifying the Source of Local Currency Price Stability." 80 Review of Economic Studies 175-210.

Gopinath, Gita and Oleg Itskhoki. 2010. "Frequency of Price Adjustment and PassThrough.” 125 Quarterly Journal of Economics 675-727. 
—. 2011. "In Search of Real Rigidities." 25 NBER Macroeconomics Annual 261309.

Gordon, Robert. 1990. “What Is New-Keynesian Economics?” 28 Journal of Economic Literature 1115-1171.

Johnson, Crawford T. 1987. Coca-Cola Bottling Company United, Inc.: A Pause to Reflect. New York, NY: The Newcomen Society of the United States.

Kackmeister, Alan. 2007. "Yesterday's Bad Times are Today's Good Old Times: Retail Price Changes in the 1890s were Smaller, Less Frequent, and More Permanent." 39 Journal of Money, Credit and Banking 1987-2020.

Kahn, E.J. Jr. 1969. Robert Winship Woodruff. Atlanta, GA: The Coca-Cola Company. Kahneman, Daniel, Jack Knetsch and Richard Thaler. 1986 "Fairness as a Constraint on Process." 76 American Economic Review 728-741.

Kashyap, Anil K. 1995. "Sticky Prices: New Evidence from Retail Catalogues." 110 Quarterly Journal of Economics 245-274.

Kaul, A. and D.R. Wittink. 1995. "Empirical Generalizations about the Impact of Advertising on Price Sensitivity and Price." 14 Marketing Science 151-160.

Klein, Benjamin and Keith B. Leffler. 1981. "The Role of Market Forces in Assuring Contractual Performance.” 89 Journal of Political Economy 615-641.

Klenow, Pete and B.A. Malin. 2011. "Microeconomic Evidence on Price-Setting," in B. Friedman and M. Woodford, eds., Handbook of Monetary Economics. New York, NY: North Holland.

Knotek, Edward S. II. 2008. "Convenient Prices, Currency, and Nominal Rigidity." 55 Journal of Monetary Economics 1303-1316. 2011. "Convenient Prices and Price Rigidity: Cross-Sectional Evidence." 93 Review of Economics and Statistics 1076-1086. 
Leahy, John. 2011. “A Survey of New Keynesian Theories of Aggregate Supply and Their Relation to Industrial Organization.” 43 Journal of Money, Credit and Banking 87-110.

Lerner, Leo. 1947. "The Pause that Refreshes." Sunday Booster. Dec. 28, 1947. [Coca-Cola Company Archive]

Levy, Daniel. 2007. "Price Rigidity and Flexibility: New Empirical Evidence Introduction to the Special Issue." 28 Managerial and Decision Economics 639647.

Levy, Daniel, Mark Bergen, Shantanu Dutta, and Robert Venable. 1997. "The Magnitude of Menu Costs: Direct Evidence from Large U.S. Supermarket Chains," 112 Quarterly Journal of Economics 791-825.

Levy, Daniel, Shantanu Dutta and Mark Bergen. 2002. "Heterogeneity in Price Rigidity: Evidence from a Case Study Using Micro-level Data.” 34 Journal of Money, Credit and Banking 197-220.

Levy, Daniel and Frank Smets. 2010. "Price Setting and Price Adjustment in Some European Union Countries: Introduction to the Special Issue." 31 Managerial and Decision Economics 63-66.

Levy, Daniel and Avichai Snir. 2013. "Shrinking Goods.” Working Paper No. 13-03, Department of Economics, Emory University.

Levy, Daniel and Andrew T. Young. 2004. "'The Real Thing': Nominal Price Rigidity of the Nickel Coke, 1886-1959." 36 Journal of Money Credit and Banking 765799.

Life. 1908. July 16, 1908. [Coca-Cola Company Archives.] 
Müller, Georg, Mark Bergen, Shantanu Dutta and Daniel Levy. 2007. "Non-Price

Rigidity and Cost of Adjustment.” 28 Managerial and Decision Economics 817832.

Munsey, Cecil. 1972. The Illustrated Guide to the Collectibles of Coca-Cola. New York, NY: Hawthorn Books, Inc.

Nation's Business. 1938. October, 1938. [01431 ARS, Coca-Cola Company Archives.] Nakamura, Emi and Jón Steinsson. 2008. "Five Facts about Prices: A Reevaluation of Menu Cost Models.” 123 Quarterly Journal of Economics 1415-1464.

—. 2011. "Price Setting in Forward-Looking Customer Markets." 58 Journal of Monetary Economics 220-233.

Nakamura, Emi and Dawit Zerom. 2010. "Accounting for Incomplete Pass-Through." 77

Review of Economic Studies 1192-1230.

Pendergrast, Mark. 1993. For God, Country and Coca-Cola: The Unauthorized

Biography of the Great American Soft Drink and the Company that Makes It. New York, NY: Simon and Schuster.

Okun, Arthur. 1981. Prices and Quantities: A Macroeconomic Analysis. Washington, DC: Brookings Institution.

Renner, Elke and Tyran, Jean-Robert. 2004. "Price Rigidity in Customer Markets." 55 Journal of Economic Behavior and Organization 575-593.

Riley, John J. 1942. Organization in the Soft Drink Industry: A History of American Bottlers of Carbonated Beverages. Washington, DC: American Bottlers of Carbonated Beverages.

- 1958. A History of the American Soft Drink Industry. Washington, DC:

American Bottlers of Carbonated Beverages. 
Romer, Christina, and David Romer. 1989. "Does Monetary Policy Matter? A New test in the spirit of Friedman and Schwartz." NBER Macro Annual 121-170. . 1994. "Monetary Policy Matters." 34 Journal of Monetary Economics 75-88.

Romer, David. 1993. "The New Keynesian Synthesis.” 7 Journal of Economic Perspectives 5-22.

Rosen, Sherwin. 1985. "Implicit Contracts: a Survey." 23 Journal of Economic Literature 1144-1175. ed. 1994. Implicit Contract Theory. Brookfield, VT: E. Edgar.

Rotemberg, Julio J. 1987. “The New Keynesian Microfoundations.” NBER Macroeconomics Annual 69-104.

- 2005. "Customer Anger at Price Increases, Changes in the Frequency of Price Adjustment and Monetary Policy." 52 Journal of Monetary Economics 829-852.

—. 2011. "Fair Pricing." 9 Journal of the European Economic Association 952981.

Saturday Evening Post. May 30 (1942). [01683 ARS, Coca-Cola Company Archives.] Schaeffer, R. and W. Bateman. 1985. "The Formula for Coca-Cola: The Old... The New." The Cola Call May, 1985: 4-6. [Coca-Cola Company Archives.]

Selgin, George. 2008. Good Money. Ann Arbor, MI: University of Michigan Press. Shapiro, Carl. 1983. "Premiums for High Quality Products as Returns to Reputations." 98 Quarterly Journal of Economics 659-680.

Tedlow, Richard S. 1990. "The Great Cola Wars: Coke vs. Pepsi." in New and Improved: The Story of Mass Marketing in America. New York: Basic Book Publishers.

Telser, L. G. 1964. "Advertising and Competition." 72 Journal of Political Economy 53762. 
—. 1980. “A Theory of Self-Enforcing Agreements." 53 The Journal of Business $27-44$.

Tyran, Jean-Robert and Dirk Engelman. 2005. "To Buy or Not to Buy? An Experimental Study of Consumer Boycotts in Retail Markets." 72 Economica 1-16.

The Ladies Home Journal. 1922. Dec., 1922. [00654 ARS, Coca-Cola Company Archives.]

The Lampmaker. 1946. "Pause that Refreshes." Nov. 22, 1946. [Coca-Cola Archives.] Time. 1950. "In One Direction Only." November 6, 1950: 9.

—. 1950. "Shave and a Haircut - \$2.35." December 25, 1950: 12.

Urban, Glen, and John Hauser. 1993. Design and Marketing of New Products, $2^{\text {nd }}$ Ed. Englewood Cliffs, NJ: Prentice Hall.

Waldman, Don and Elizabeth Jensen. 2001. Industrial Organization: Theory and Practice, $2^{\text {nd }}$ Ed. Boston, MA: Addison-Wesley.

Weiss, Yoram. 1993. "Inflation and Price Adjustment: a Survey of Findings from MicroData." in Optimal Pricing, Inflation, and the Cost of Price Adjustment, E. Sheshinski and Y. Weiss, eds. Cambridge, MA: The MIT Press.

Willis, Jonathan. 2003. "Implications of Structural Changes in the U.S. Economy for Pricing Behavior and Inflation Dynamics.” Federal Reserve Bank of Kansas City Review, $1^{\text {st }}$ Quarter, 5-27.

Wolman, Alex. 2007. “The Frequency and Costs of Individual Price Adjustment: A Survey." 28 Managerial and Decision Economics 531-552.

Worthington Globe. 1946. "Dime 'Cokes'." November, 1946. [Coca-Cola Company Archives.] 
Young, T. Andrew and Alex Blue. 2007. "Retail Prices during a Change in Monetary Regimes: Evidence from Sears, Roebuck Catalogs, 1938-1951." 28 Managerial and Decision Economics 763-775.

Young, James. 1983. "Three Southern Food and Drug Cases." 49 Journal of Southern History 3-36.

Zbaracki, Mark, Mark Ritson, Daniel Levy, Shantanu, Dutta and Mark Bergen. 2004. "The Managerial and Customer Costs of Price Adjustment: Direct Evidence from Industrial Markets." 86 Review of Economics and Statistics 514-533.

Zhen, Chen, Michael Wohlgenant, Shawn Karns and Phillip Kaufman. 2011. "Habit Formation and Demand for Sugar-Sweetened Beverages.” 93 American Journal of Agricultural Economics 175-193.

\section{Court Cases}

The Coca-Cola Bottling Company v. The Coca-Cola Company. Fulton County Superior Court, Georgia, 1920.

The Coca-Cola Bottling Company v. The Coca-Cola Company. US District Court, Delaware, 1920.

The Coca-Cola Company v. The Koke Company of America. 254 US 143, 41 Supreme Court 113, 1920.

Rucker, Henry A. v. The Coca-Cola Company. US Circuit Court, District of Georgia.

(Trial and Appeal Record, Federal Record Center, East Point, Georgia.)

United States v. Forty Barrels and Twenty Kegs of Coca-Cola, 241 US 265, 289. (Record of Appeal from the Federal Records Center, East Point, Georgia.)

\section{Coca-Cola Company Documents}


Advertisement No. S-2 and S-3, 1945, the Coca-Cola Company Archives.

Advertising Copy Collection, 0009 ARS, 00349 ARS, 00502 ARS, 01625 ARS, 01714 ARS, 00496 ARS, and 02815 ARS, the Coca-Cola Company Archives.

Advertising Copy Collection, "Chain Store Age (Grocery Managers' Edition) — August, 1942," the Coca-Cola Company Archives.

Always Coca-Cola: A Quick Reference Chronology from 1886 to 1993. Coca-Cola Company, 1993.

Annual Report to Stockholders for the Year 1920. The Coca-Cola Company, February, 1921.

Annual Report to Stockholders for the Year 1924. The Coca-Cola Company, February, 1925.

Candler, Charles Howard. The True Origin of Coca-Cola. Unpublished Manuscript: the Coca-Cola Company Archives, 1952.

Did You Know? Atlanta: the Coca-Cola Company Public Relations Dept., undated.

Fact Sheet: Product Structure of Coca-Cola USA. Atlanta: the Coca-Cola Company Consumer Information Center, 1983.

Fact Sheets Concerning the Nickel Price. Atlanta: the Coca-Cola Company Public Relations Department, undated.

Ford, Harrison. Cost of Manufacturing Merchandise No. 5, Memo to Robert Woodruff, the Coca-Cola Company Archive, July 28 (1930).

Griffiths, Fred. "The Price Question." The Red Barrel June (1934): 2-6.

Hayes, Ralph. Letter to William J. Hobbes. July 26, 1948. the Coca-Cola Archives.

Hayes, Ralph. Letter to Robert W. Woodruff. May 5, 1954. Robert W. Woodruff Papers, Special Collections, Emory University Library. 
Henry, Harvey. "Predatory Price Cutting Must Be Ended." The Red Barrel Dec. (1933): $2-3$.

“Instructions for Salesmen in Campaign for Promoting 5ф Price on Coca-Cola." Undated. the Coca-Cola Company Archives.

Jackson, George P. "Confidential" Memo Sent to Robert W. Woodruff by Cliff Roberts. May 10, 1944. Robert W. Woodruff Papers, Emory University.

Kahn, E. J. Jr. Robert Winship Woodruff. Atlanta: the Coca-Cola Company, 1969. Landers, William A. "My 38 Years with the Coca-Cola Company." Unpublished Manuscript. the Coca-Cola Company Archives, 1950.

"Letter to Bottlers on Price." 1959, the Coca-Cola Company Archives.

Nicholson, H.B. Letter to Pope F. Brock. August 23, 1950. Coca-Cola Archives.

Nicholson, H.B. "Memorandum to: Mr. Nicholson.” January 26, 1951. the Coca-Cola Company Archives.

Office of Production Management. Order M-55, December 13, 1941, the Coca-Cola Company Archives.

"Profit and Price Promotion." 1950, the Coca-Cola Company Archives.

"Results of the Coca-Cola Price Rise." October 12, 1950. the Coca-Cola Archives. Reviewing "A Proud History" 1886 to 1925. Atlanta: the Coca-Cola Company, 1925.

Stryker, Lloyd Paul. Letter to John M. Drescher. March 14, 1940. the Coca-Cola Company Archives.

The Coca-Cola Bottler. Atlanta: The Coca-Cola Company, various years (May 1909, June 1909, March 1910, June 1918, Sep. 1918, Jan. 1944, April 1944, July 1944, Dec. 1944, April 1946, June 1947, Sept. 1947, Nov. 1947, and April 1959). The Coca-Cola Company. "Guaranteed Under the Pure Food and Drug Act." Advertisement Print from the Coca-Cola Company Archives. 
“The Price Situation.” February 21, 1951, the Coca-Cola Company Archives.

Toigo, John. Memo to H. Burke Nicholson. November 7, 1950. Coca-Cola Archives.

Trade Paper Insert, 1923, the Coca-Cola Company Archives.

Unsigned. Letter to F.E. Riggs. June 28, 1950, the Coca-Cola Archives.

Woodruff, Robert W. Letter to Arthur Acklin. October 2, 1942. Robert Woodruff Papers, Special Collections, Emory University Library. 
Table 1. Cost of Raw Materials as Percent of Soft-Drink Industry Production and Coca-Cola Advertising as Percent of Sales, Select Years, 1879-1955

\begin{tabular}{lcc}
\hline \hline Year & $\begin{array}{r}\text { Raw Materials' Cost Share in } \\
\text { Soft Drink Industry }\end{array}$ & $\begin{array}{c}\text { Coca-Cola } \\
\text { Advertising Share }\end{array}$ \\
\hline 1879 & 0.441 & - \\
1889 & 0.318 & - \\
1899 & 0.368 & 0.123 \\
1909 & 0.379 & 0.167 \\
1919 & 0.507 & 0.081 \\
1930 & 0.478 & 0.112 \\
1940 & 0.420 & 0.089 \\
1950 & 0.385 & \\
1955 & 0.430 & \\
\hline
\end{tabular}

Sources: Raw materials share is from Riley (1958). Percentages are computed using data on value of production, number of plants, and average raw materials used per plant. Advertising expenditures are from "The Coca-Cola Company Advertising Expenditures," a Coca-Cola Archives document. Sales are from "Sales of Coca-Cola," a Coca-Cola Archives document. 
Table 2. Advertising Material Distributed by the Coca-Cola Company in 1913

\begin{tabular}{|c|c|}
\hline Amount & Item \\
\hline 200,000 & 4-head cutouts for window display \\
\hline $5,000,000$ & Lithograph metal signs from 6" X $10^{\prime \prime}$ to 5 ' X 8' \\
\hline 10,000 & Enamel metal signs $12 " \mathrm{X} 36 ", 18 ” \mathrm{X} 45 "$ \\
\hline 60,000 & Fountain festoons \\
\hline 250,000 & Special signs for bottlers 12 " X 36 " \\
\hline 50,000 & Cardboard cutouts for window display \\
\hline 60,000 & 4-head festoons for soda fountains \\
\hline 10,000 & Lithograph metal display signs \\
\hline 20,000 & Lithograph metal display containing reproduction of bottles \\
\hline 50,000 & Metal signs for tacking under windows \\
\hline 200,000 & Fiber signs for tacking on walls of refreshment stands \\
\hline $2,000,000$ & Trays for soda fountains \\
\hline 50,000 & Window trims \\
\hline 250,000 & 5-head window displays and mirror decorations \\
\hline $1,000,000$ & Japanese fans \\
\hline 50,000 & Christmas wreaths and bell decorations for fountains \\
\hline 50,000 & The Coca-Cola Company song \\
\hline $1,000,000$ & Calendars \\
\hline 50,000 & Thermometers \\
\hline $10,000,000$ & Match books \\
\hline $50,000,000$ & Doilies (paper) \\
\hline 10,000 & Large calendars for business offices \\
\hline 144,000 & Pencils \\
\hline 20,000 & Blotters \\
\hline 10,000 & Framed metal signs for well displays \\
\hline 5,000 & Transparent globes, mosaic art glasswork \\
\hline 25,000 & Baseball score cards \\
\hline$\$ 300,000$ & Newspaper advertising \\
\hline
\end{tabular}

Source: Tedlow (1990, Exhibit 2-1, p. 53) 